\title{
TTR
}

Traduction, terminologie, re?daction

\section{Wolfgang Lörscher. Translation Performance, Translation Process, and Translation Strategies. A Psycholinguistic Investigation. Tübingen, Gunter Narr, 1991, 307 p.}

\section{Candace Séguinot}

Volume 5, numéro 1, 1er semestre 1992

La pédagogie de la traduction : questions actuelles (1) et Miscellanées traductologiques

URI : https://id.erudit.org/iderudit/014625ar

DOI : https://doi.org/10.7202/014625ar

Aller au sommaire du numéro

Éditeur(s)

Association canadienne de traductologie

ISSN

0835-8443 (imprimé)

1708-2188 (numérique)

Découvrir la revue

Citer ce compte rendu

Séguinot, C. (1992). Compte rendu de [Wolfgang Lörscher. Translation Performance, Translation Process, and Translation Strategies. A Psycholinguistic Investigation. Tübingen, Gunter Narr, 1991, 307 p.] TTR, 5(1), 271-275.

https://doi.org/10.7202/014625ar d'utilisation que vous pouvez consulter en ligne.

https://apropos.erudit.org/fr/usagers/politique-dutilisation/ 
français. Pour leur part, l'abbé Jacques Delille et Étienne-Augustin de Wailly voient dans la pratique des traductions un instrument idéal d'enrichissement de la langue, un antidote contre la sclérose de l'expression.

En interrogeant les textes, il devient possible de connaître les devoirs que s'imposent les traducteurs au regard des qualités d'une bonne traduction. On découvre ainsi les multiples qualités dont doivent se parer les traductions, compte tenu des contraintes de tout ordre imposées par la culture adoptive. Vigny rappelle, non sans ironie, que les timides traducteurs français de Shakespeare ont mis 98 ans avant de se décider à dire tout haut sur scène un mouchoir!

En relisant ces anciens textes, on découvre que plusieurs notions contemporaines de la traductologie y sont présentes en germe. MarieClaude-Frédéric Vautier définit en 1812 les notions de «compensation» et d' «équivalence» d'une manière que ne récuseraient pas les comparatistes modernes. Beauzée, quant à lui, distingue habilement «version» et «traduction».

En somme, Cent ans de théorie française de la traduction fournit aux historiens de la traduction un riche matériau qu'ils sauront exploiter avec profit, je n'en doute pas. Cet ouvrage bien fait et présenté sous une fort jolie couverture, trouvera aussi une grande utilité en enseignement, puisque, comme il a déjà été dit, les études sur cette période sont peu nombreuses. «Le style de l'histoire, a écrit Charles Batteux, doit être clair, aisé, coulant et toujours soutenu» (p. 32). Telles sont les qualités de l'ouvrage de Lieven D'Hulst, qui a produit une cuvre utile et de haute tenue. Espérons qu'elle sera suivie de nombreuses autres.

Jean Delisle

Université d'Ottawa

\section{Wolfgang LÖRSCHER. Translation Performance, Translation Process, and Translation Strategies. A Psycho- linguistic Investigation. Tübingen, Gunter Narr, 1991. 307 p.}

Anyone interested in observational studies of translation will no doubt be familiar with the work of Wolfgang Lörscher through his recent articles on 
the translation process. For those of us whose knowledge of German is less than adequate, the fact that his 1987 professorial dissertation or Habilitationsschrift from the University of Essen, Überstzungsperformanz, Übersetzungs-prozeß und Übersetzungsstrategien. Eine psycholinguistische Untersuchung, has been published in English is very welcome news. In this book, as in his articles, Lörscher can be counted on to provide a thorough explanation of the current thinking in cognitive psychology and language learning relevant to the interpretation of data-driven research in translation. There is a section on thinking aloud as a way of collecting data (pp. 48-55), an interesting discussion of interpretive reconstruction (pp. 56-59) and a lengthy explanation of different concepts of strategy and text production models (pp. 67-81).

This material provides the background for the experimental hypotheses underlying the psycholinguistic investigation of the subtitle. The strength of the actual data and the subsequent analysis lies in the theoretical and methodological issues that they raise. There is no escaping the fact that the grammar-translation method of language teaching which is alive and well and living in Germany is anathema to Canadians, and especially to Canadians who teach in schools of translation. If this point seems to be parochial, it is nevertheless central to the reader's willingness to accept generalizations about the translation process given the specifics of the experimental design.

The subjects for the study were university students in English as a foreign language courses who had little experience translating, and very little translation training; they had varying degrees of competency in the foreign language itself. The task that they were asked to perform was an orally-produced translation of a written source text. Half the subjects translated one of six English texts toward German, their mother tongue, and the other half translated one of three German texts toward English. At the same time as they were producing their translations orally, the students were asked to think aloud about the process itself. "Whoa!" says the reader. Can you really call what the subjects are doing translating, and if so, does that imply that the strategies they use to problem solve are the same as those used by expert translators? And is it really possible to translate aloud and think aloud at the same time?

To his credit, Lörscher anticipates these and other objections throughout the work. He begins (p. 3) by justifying the use of "nonprofessional translators" in two ways. First, his hypothesis is that "every 
individual with a command of two or more languages also possesses a rudimentary ability to mediate between these languages." And second (p. 35), he believes that professional translators have reached a much higher degree of automatization in translation, and since little thinking out loud is to be found in phases of automatic language processing, "hardly any data from which aspects of the translation process could be interpreted would be externalized." The problem with the latter argument is that we know from more recent studies that think-aloud protocols can be collected from professional translators, producing very limited data, true, but interesting results nonetheless. There is of course another argument the author could have made in defense of using students: he managed to collect 52 translations from 48 subjects, a very large number that would have been impossible to reach without a student body to draw on.

The author's first hypothesis is more central because it makes some claims about the nature of the ability to translate, as he explains further (p. 44), "Since bilingualism and bilingual competence can only be achieved approximately, the logical consequence is to hypothesize as well a rudimentary ability to mediate information between languages for people who are in possession of a mother tongue and an interlanguage, and to consider their mediations as translations in a broad sense." The thesis of similarity rather than difference places certain restrictions on the kind of findings that can be expected; it precludes, for example, the hypothesis that translation carried out by experts will be different from translations carried out by non-experts. This also explains perhaps why the author tries to look for shared translation problems, meaning things like the ratio of problematic versus non-problematic lexical items (problematic in terms of the technical definition of success) (pp. 212-217).

The subjects paid little attention to stylistic and text-type adequacy (p. 90), presumably functioning on the basis of their only previous experience which was translation in a language testing situation. This raises another issue, namely the interpretation of what is actually a translation strategy. The author defines a translation strategy (p. 76) as "a potentially conscious procedure for the solution of a problem which an individual is faced with when translating a text segment from one language to another." No distinction is made between a second language problem and a translation problem for both practical and epistemological reasons (pp. 93-94). A problem is defined from the point of view of the subject; the researcher recognizes that there is a translation problem when a student realizes that he or she "is unable to transfer or to transfer adequately a source-language 
text segment into the target language." A strategy is deemed successful in resolving the problem if the subject was able to produce something for the souce language segment in question and did not comment that it was inadequate. Given this subject orientation, there was no analysis of the quality of the translations or record of errors. This raises an interesting question: a distinction is commonly made for second language communication strategies between strategies directed toward accuracy and strategies directed toward fluency. Could that also be the case for student translation strategies? Given the fact that students were not allowed dictionaries, the pressure for achieving accuracy was less than if they had had access to reference material. The fact that the production was oral made it difficult to leave gaps. In a sense then, the orientation was toward production or fluency, and it makes sense to ask, again based on a comparison with second language learners, whether what they were doing should be called translation strategies or coping strategies.

Lörscher's thesis that there are two kinds of translation, nonstrategic, or automatic translation, and strategic, which involves problemsolving (p. 88), is central to his investigation. When he defends the oral production of the translations, it is with reference to this distinction: "...it does not seem to be very likely that the linguistic medium of the texts to be translated has any decisive influence on those aspects of the translation process which are the object of this investigation, i.e. on translation strategies as procedures for solving translation problems." How, then, were the subjects able to backtrack to check on tense and pronoun and person agreement in the target text? Put another way, is the finding that subjects' approach to translations (p. 264) is "...almost exlusively sentence-, clause-, or even word-oriented" surprising given the oral form of production?

Lörscher proposes (pp. 123-129) a formalized analysis of translation strategies into elements based on a corpus of fourteen translations and provides examples of his transcriptions. Because these elements are closely tied to the design of the experiment - one could expect the category 'Verbalizing a problem' when subjects are asked to think aloud - it is difficult to judge the broader applicability of the categories.

The author explicitly states that his interest is not research into foreign language teaching and learning (pp. 93-94), but teachers of foreign languages who use translation may find his discussion of strategies revealing. And on a more general note, it was interesting to read the author's finding that there are differences between strategies of translation 
into and from the mother tongue, but that these are of degree, and not of kind (p. 264).

Candace Séguinot York University

\section{Lynn Visson. From Russian into English, An Introduction to Simultaneous Interpretation. Ann Arbor, Michigan, Ardis Publishers, 1991, 266 pp.}

This book is addressed to advanced Russian students wishing to interpret into English and also to people who study or work with Russian; nevertheless, the level of linguistic and translational competence it assumes on the part of its readership is - justifiably, it would seem - very low indeed. The work has its merits, let alone the sheer fact that it exists, there being such a dearth of useful didactic material. It is indeed very entertaining and, to the uninitiated, quite informative. Its main virtue, to my mind, is that through most illuminating examples it shows how inane - or downright damaging - literal translation really is.

It is organised in a preface, an introduction and two parts, one on "Practical Problems," and a second one devoted to "Selected Practice Texts and Vocabulary." In the introduction the author starts by berating - justly, I think - the theory that it is better to interpret from one's native language (which its Soviet proponents systematically apply to interpretation from Russian, but never into it) and then provides a raw analysis of the differences between translating and interpreting.

Part I starts with a chapter titled "The Simultaneous Interpreter: Who He Is and What He Does." After a short historical introduction leading to a discussion of the logistics of interpretation at the UN and in the Soviet Union, comes the first of a series of practical advice: "Special attention is paid to the very beginning and the very end of the speech, for here errors will be in the spotlight" (p. 18). A lot of variegated ground is skimmed over in a few pages; equally touched upon, among a myriad other momentous things and minutiae, are the need to go beyond words, the elementary rules of booth behaviour, the psychology of the interpreter, the typical amounts of syllables per minute uttered in different languages in different settings, and probability prediction, as well as the problem of singular and plural case endings. Finally, it is rightly stated that "interpreta- 